\title{
Vems röst?
}

\section{Ida Al Fakir}

Ligger historieforskningens värde i dess innehåll eller bestäms värdet utifrån vem som producerar innehållet? Är kunskap sprungen ur ett "inifrånperspektiv" mer giltig än den som producerats av någon "utomstående"? Diskussionen om vems röst som hörs och vems historia som skrivs är högaktuell. Den utgör en viktig del i den ständigt pågående "Kampen om Historien". De senaste decenniernas utveckling inom historievetenskapen har inneburit en breddning och en diversifiering av teorianvändning och forskningsområden. Bland annat anläggs intersektionella och postkoloniala perspektiv på såväl "gammalt" som nytt källmaterial och bildar grund för nya infallsvinklar på sedan länge diskuterade historiska problem. Tidigare osynliggjorda, förbisedda och marginaliserade minoritetsgruppers historier har nu förlänats plats på historiens upplysta scen. Men vem är det som skriver dessa historier? Spelar det någon roll vems röst det är vi hör så länge rösten talar om de "rätta" problemen?

Frågorna som väcks är angelägna men svåra att besvara. De rör komplexa och i viss mån subjektiva begrepp som identitet, representativitet och autenticitet. Vem ska och kan skriva aboriginernas, samernas, indianernas, romernas historier? Måste man identifiera sig som tillhörande gruppen för att kunna göra anspråk på att skriva representativ historia? Eller är det möjligt att producera historisk kunskap som minoritetsgrupper kan identifiera som sin, som kan ses som representativ för åtminstone delar av gruppen, utan att själv identifiera sig eller identifieras som tillhörande en minoritetsgrupp? Bland en del forskare med minoritetsbakgrund kan det synas självklart att "riktig" kunskap endast kan nås genom personlig erfarenhet av och delade villkor med minoritetsgruppen. Denna identitet förutan saknar man de "glasögon" som behövs för att se det unika och/eller det avvikande. Den kanoniserade litteraturforskaren Edward Said (som tillhörde en arabisk/palestinsk minoritet i USA) detroniserar i sin bok Orientalism de västerländska forskare, författare och politiker som han menar har konstruerat en verklighetsfrånvänd bild av Orienten och orientalen. Men, menar Said, orsaken ska inte sökas i deras västerländskhet eller i en frånvaro av äkta förståelse för Orienten - insider-perspektivet är inte alltid överlägset outsiderperspektivet.

I Australien utgör aboriginernas historia ett stridsfält i den nationella historieskrivningen. Debatten kallas för The History Wars och är i hög grad politiserad. Kombattanterna, bestående av vita intellektuella australier, inordnar sig på en höger-vänsterskala. Aboriginer är generellt sett inte delaktiga i denna Kamp om Historien utan har reducerats till politiskt slagträ. Marginalisering och diskriminering blir en politisk fråga snarare än ett nationellt historiskt arv, vilket möjliggör fortsatt förnekelse av Australiens koloniala förflutna. Men för att Kampen ska leda till förändring bortom nästa val är det viktigt att även aboriginer äntrar slagfältet. På så sätt kan konfliktens natur ändras, den kan bli en katalysator för fred, menar den australiensiska historikern och aboriginen Vicki Grieves. Hon beskriver den vita australiensiska nationalstatens syn på aboriginer som tomma behållare som ska fyllas med västerländsk kunskap utan något eget att bidra med till nationens intellektuella liv. Grieves ser sig i egenskap av aborigin som fångad i den västerländska epistemologins hegemoniska kolonialism; aboriginska intellektuella måste fortfarande kämpa för att göra sin röst hörd. Två argument för representativitet kan utläsas i den australiensiska debatten: Det ena rör den aboriginska intellektuella kunskapens specifika förklarande funktioner, opåver- 
kad av västerländsk epistemologi och pedagogik och med bevarade andliga och heliga dimensioner. Det andra bygger på att forskare tillhörande den vita majoriteten inte kan frigöra sig från det västerländska koloniala kunskapsarvet och traditionen, och därmed reproduceras och förstärks de förtryckande mekanismer som ofta är tänkta att motarbetas.

Även andra forskningsfält brottas med representationsproblematiken. Till exempel påpekar etnologen Gregor Dufunia Kwiek, som själv tillhör en romsk minoritet, att minoritetsskapet kan leda till att en forskare automatiskt men oförtjänt utses till expert. Han exemplifierar med en akademiker i USA som sent i karriären fick vetskap om sina indianska förfäder. Hon hade därmed både de vetenskapliga verktygen och det etniska ursprunget, och utsågs till en auktoritet på området utan att egentligen ha någon erfarenhet som indian. Omvänt blir det problematiskt när en utomstående forskare strävar efter att ge en representativ bild av en etnisk minoritet, men använder sig av källor som samlar information utifrån vissa begränsade sociala omständigheter. Ett exempel på detta är etnologen Karl-Olov Arnstbergs försök att ringa in den romska kulturen genom att analysera material hämtat från Socialstyrelsen, i vars arkiv huvudsakligen personer med sociala och/eller ekonomiska problem hamnar. Chansen att bland dessa dokument finna självförsörjande och framgångsrika romer är således ganska små, och slutsatser som dras om den "romska kulturen" utifrån dokumenten blir förvrängda.

För historikern är frågan om representativitet nödvändig att förhålla sig till och reflektera kring. Detta gäller oavsett forskningsområde, men i synnerhet om man i sin forskning berör marginaliserade och/eller minoritetsgrupper. Samtidigt kan frågan leda fel, då representativitet i någon mån är ouppnåeligt. Den som i ena sakfrågan kan representera en specifik grupp, kan i nästa fråga vara orepresentativ på grund av kön, etnicitet, kultur, klass, generation, religion etcetera. Att sträva efter representativitet kanske i själva verket är ett lönlöst företag, men vad ska man i så fall göra? En möjlig väg kan vara att göra själva kunskapsproduktionen mer genomskinlig, det vill säga att historikerns - producentens - bakgrund och bevekelsegrunder lyfts fram som en del av den vetenskapliga processen. Om utgångspunkten är att objektiv sanning inte existerar, men att historisk kunskap ändå går att nå utifrån den enskildes horisont och i diskussion med tidigare forskning, då kan man konstatera att den individuelle historikerns roll är förhållandevis framträdande. Är det då inte bättre att låta historikern bli en självklar del av sin berättelse? I nordamerikansk forskning är det inte ovanligt att läsa författarpresentationer och förord där forskaren beskrivs som exempelvis feminist historian eller att utgångspunkten för studien varit att skriva anti-racist history. Detta är svårare att föreställa sig i en svensk akademisk kontext, men kanske kan den amerikanska formen av öppenhet och konkreta ställningstaganden fungera som en katalysator i den till synes olösliga problematiken kring representativitet?

Mot argumentet att representativitet inte är möjligt eller ens eftersträvansvärt inom historieforskningen kan hävdas att representation i grund och botten är en kvantitativ snarare än kvalitativ fråga. Det skulle således vara mängden praktiserande aboriginska eller romska historiker som spelar roll, och inte den individuella romska eller aboriginska forskarens resultat. Detta håller även jag för sant - kvantitativ representation är utan tvekan viktigt inte minst för att levandehålla ett kritiskt vetenskapligt samtal. En forskare med minoritetsbakgrund ses ofta, vare sig hon/han vill, som representativ för sin grupp, vilket också kan implicera en automatisk auktoritet i sakfrågor, något som diskuterats ovan. Men liknande problematik kringgås om det finns en mängd forskare från samma minoritetsgrupp som kan kritisera varandras forskning och med detta skapa en sorts diversifierad representativitet som tar hänsyn till intersektionella mekanismer. Kvantitet kan 
på detta sätt sägas borga för kvalitet genom att främja ett livaktigt och mångröstat kritiskt samtal. Med detta är inte sagt att varje individuell forskare med bakgrund i en minoritetsgrupp bedriver bättre forskning inom och om sin grupp än vad en forskare tillhörande majoriteten gör, eller att denna forskning automatiskt åstadkommer mer för gruppens sociala, kulturella, politiska och ekonomiska status. Enligt samma resonemang kan man fastslå att den utomstående forskarens förmodade utanförskap, tvärtemot vad somliga hävdat, inte medför en "klarare" blick på minoriteten.

Kanske är det så att representativitet inte bör eftersträvas av den enskilde forskaren därför att det, på samma sätt som det är omöjligt att skildra en slutgiltig och sann historia, aldrig är möjligt att skildra allas historia? Det viktigaste skulle då inte vara den etniska, sociala, kulturella, geografiska eller politiska representativiteten, utan att tolkningsrätten och tolkningsfriheten läggs i läsarens händer genom ett synliggörande av den producerade kunskapens själva fundament. Det vill säga att historikern, innan hon/han ger sig i kast med Vad, Hur och Varför, besvarar frågan Vems röst?

\section{Referenser}

Arnstberg, Karl-Olov, 1998, Svenskar och zigenare: en etnologisk studie av samspelet över en kulturell gräns. Stockholm: Carlsson.

Dufunia Kwiek, Gregor, 2009, "Romani Studies \& its Missing Elements" opublicerat paper presenterat på Stockholm International Conference on the Discrimination and Persecution of Roma, Sinti and Travellers. Stockholms universitet, 5-7 mars 2009.

Grieves, Vicki, 2008, 'The 'Battlefields': Identity, Authenticity and Aboriginal Knowledges in Australia" i Minde, Henry (red.) Indigenous peoples: self-determination, knowledge and indigeneity. Delft: Eburon.

Macintyre, Stuart \& Clark, Anna, 2004, The history wars. New ed. Melbourne: Melbourne University Press.

Said, Edward W., 1993, Orientalism. Stockholm: Ordfront 